\title{
Managing Customer Participation and Customer Interactions in Service Delivery: the Case of Museums and Educational Services
}

\author{
Marlene Amorim, Maria João Rosa, Sandra Santos
}

University of Aveiro, Department of Economics, Management and Industrial Engineering, Aveiro, Portugal, mamorim@ua.pt (corresponding author), m.joao@ua.pt, sipsantos@ua.pt

Background and Purpose - In this study we investigate determinants of customers' quality perceptions in service processes which involve customer participation and customer to customer interaction (CCl). Building on existing multidimensional approaches to service quality we explore relevant quality aspects for related to the performance customer participation and $\mathrm{CCl}$.

Design/Methodology/Approach - The study builds on focus groups conduct with employees and customers of a leading provider of educational and science services, which offered a portfolio of service activities requiring very diverse levels of customer participation and $\mathrm{CCl}$, to characterize service quality dimensions.

Results - The study distinguishes three dimensions of service delivery quality: a dimension related to the providers' direct performance; a second dimension relative to the performance of customers' own participation in service activities, and a third dimension relative to the interaction with other customers. The work extends service quality literature by identifying new dimensions which affect service quality in service settings with active customer involvement.

Conclusion - Service providers have been developing very diverse delivery processes, frequently inviting customers to have active roles in service production. Often, customers also interact with other costumers in service delivery. The paper provides a contribution to foster the debate about service quality frameworks, and aims to inform the design and the management of services where customer participation and $\mathrm{CCl}$ have a key role.

Keywords: service quality, customer participation, customer-to customer interaction

\section{Introduction}

Customers assess the quality of a service by evaluating various outputs in a delivery process. Johnston and Clark (2005) distinguished a direct result (the core output of a service, such as a meal in a restaurant) and an experience outcome (the way the customer is dealt in the delivery). Other authors, such as Roth and Menor (2003) identified dimensions of explicit and implicit service outputs. Research results also evidenced that when service results are difficult to assess (e.g. because of their intangibility, such as in education services), customers often rely on service process clues for inferring about service quality (Rosenbaum and Massiah, 2011; Baker and Lamb, 1994).

Extant quality models capture such multidimensional nature of service outputs (Martínez and Martínez, 2010). Seminal conceptualizations include the work of Gronroos (1993), which distinguishes dimensions of technical and functional quality, and SERVQUAL (Parasuraman et al. 1991,1988) which identified five quality dimensions: tan-

Received: September $6^{\text {th }}, 2013$; revised: $19^{\text {th }}$ July 2014; accepted; July $29^{\text {th }}, 2014$ 
gibility, responsiveness, assurance, reliability and empathy. These models have been successfully applied across the diverse universe of service industries (Ladhari, 2009). They seem, however, less fit to describe service quality for delivery processes which have distinct operational characteristics.

Quality models typically address service processes with substantial volume of customer-employee interactions and customer contact with tangible elements (e.g. service facilities). Yet, service providers have been developing very diverse delivery processes, frequently inviting customers to have active roles in service production (e.g. adopting selfservice technologies), and therefore affecting service quality (Payne et al., 2008). Often, as well, customers interact with other costumers in service delivery (e.g. customers frequently provide instructions and assistance to each other in service settings). Both customer participation and customerto-customer interaction (CCI) can have substantial impacts for service results (Frei, 2006; Nichols, 2005, 2010) and consequently for customers' quality perceptions (Bendapudi and Leone, 2003). Nevertheless these aspects are not explicitly integrated in the prevalent quality frameworks, which are used to support service research and management (Kelley et al., 1992).

We need to expand service quality frameworks, in order to meet the diverse service delivery processes offered by providers. In particular, we need to look at service processes involving distinct degrees of customer participation and $\mathrm{CCI}$, to understand its influence for service results and customers' quality perceptions. Our work aims to provide a contribution to this field. We are conducted a case study with a leading provider of educational, and science, events, targeted to both adult and children audiences. The organization conducts service activities requiring very diverse levels of customer participation and CCI, therefore providing a rich portfolio of service delivery processes for our study.

The primary goal of the study was to investigate how the operational characteristics of the service delivery (e.g. customer participation and $\mathrm{CCI}$ ) contribute to inform customers' quality assessments. The study sets out to identify service quality dimensions associated to the characteristics of providers and customers which influence service outputs and quality.

The paper is structured as follows. We first provide the conceptual background of our study, reviewing the conceptualization of quality service literature, notably the multidimensional nature of the service quality construct. We also provide a review of the characterization and implications of customer participation and CCI in services. In the methodology section we describe the objectives of the study and the data collection and data analysis methods. Finally we provide a discussion of the results of the work, and we draw some managerial implications and directions for future research.

\section{Conceptual background}

\subsection{Service Quality}

The outputs of a service process are considerably more difficult to specify and evaluate than those of pure manufacturing processes (Goldstein et al., 2002). The results obtained in many services can involve intangible components, which can be difficult to specify and assess (Lovelock and Wirtz, 2001; Grönroos and Ojasalo, 2004). Moreover, as customers participate in the service process, they evaluate both the final outcome of service delivery and how the service was delivered and how good their personal experience was (Mohr and Bitner, 1995, Grönroos and Ojasalo, 2004).

Service process experiences can be positive when customers enjoy some of the process participation itself, for example, because of fun elements and socialization aspects related to the interaction with other customer or employees (Burke, 2002). But it may also be perceived negatively because it will involve some personal time and effort to reach or contact the service facilities and for completing the service delivery. In many cases, the process experience can dominate the overall value perception of the customer and be even more important for the customer than the service direct results (Grönroos, 1998).

The definition of specific performance measures to evaluate the quality of the service delivery in each of these value dimensions is complex. The SERVQUAL model by Parasuraman et al. (1988) is probably the most widely accepted model to develop adequate measures of service quality. The model defines 5 dimensions to measure service quality: tangible elements, reliability (performing the service accurately and consistently), responsiveness (providing the service fast), assurance (delivering the service in a competent and credible manner) and empathy (offer care, courtesy and individualized attention). Other authors developed similar approaches adding new dimensions to address specificities of particular service contexts. For example, Parasuraman et al. (2005) developed ES-QUAL and E-RecS-QUAL for the specific case of electronic retail services quality and the quality of service recovery, introducing dimensions such as efficiency, fulfillment, system availability or privacy, to address specifi service attributes related to customer-technology interactions. Similar efforts can be found in the literature about retail services, with the retail service quality scale (RSQS) consisting of five dimensions: physical aspects, reliability, personal interaction, problem solving and policy Dabholkar et al. (1996). The RSQS measurement scale includes some general service quality items, inspired in SERVQUAL, as well as items related to specific aspects of retail services such as, the layout of the store its adequacy to customers' browsing and picking of products (in the physical aspects dimension), or the quality of the merchandise (in the policy dimension). Whereas customer participation and CCI have been acknowledged as 
an important feature in many service settings, extant service measurement scale, don't include specific items or dimensions related to the performance of the customer actions or the interaction with others. The purpose of this study is to provide a contribution to this body of knowledge.

\subsection{Customer participation}

Customer participation has been acknowledged as a key distinguishing feature of service process (Sampson, 2000). Customers provide very diverse inputs for service production, notably the presence of the customer himself (as it in the case of healthcare or personal services); some material or immaterial customer possessions (personal objects to be transported, cleaned, repaired); and frequently, customer information (Lovelock and Gummesson, 2004; Sampson and Froehle, 2006). Consequently, service processes typically involve a great deal of interaction between the customers and the service employees, as well as the commitment of personal time and effort to engage in the service delivery (Mills and Margulies, 1980, Chase, 1981, Mills et al., 1983).

Customers have been progressively encouraged to perform more active roles in service production. Some authors have suggested long ago that companies can use customers to replace the employees in some operations as a source of productivity gains (Mills and Morris, 1986). More recently, the concept of co-production has been extended to consider customer contributions in more general instances. In the strategic management literature, this is often referred to as "value co-creation" (Prahalad and Ramaswamy, 2004). Building on previous work, Sampson (2007) defined seven possible types of generic roles a customer can perform in services: supplier, labor, design engineer, product, inventory, quality assurance, and competitor.

Increasing the extent of customer participation in services, however, does not come without a cost. The quality of the resulting service becomes, at least partially, dependent on the quality of the collaboration between the customer and the provider (Heinonen et al. 2013; Cheung and To, 2011). As Frei (2006) noted, customers can introduce substantial variability in service process operations and outputs, due, for example to their lack of capabilities to perform the service delivery operations required from them, or just because they don't have enough motivation of incentive to do so. As such, in services involving substantial customer participation, diverse types of customer failures, and low performance situations can occur (Ford and Dickson, 2012).

For service providers customer participation creates the need to design service processes in a robust way, to incorporate customer contributions in a seamless way which doesn't affect efficiency and customer value. Examples of these efforts include the creation of clear customer instruction and scripts to guide customer roles and actions in service delivery (Tax et al. 2006). Moreover, customer failure, or misbehavior will affect not only the quality of his own outputs, but also the results and the experience provided to other customer sharing the same service settings (e.g. smoking in the non-smoking area of a restaurant, talking in an overly loud voice late at night in a hotel hallway, talking on cell phones during a movie, etc.) (Huang et. al 2010). Customer participation has effects for customer service quality perceptions, particularly in the case of service failures, or when delivery fall below certain expected level. For example, in service settings which ask from customers a high degree of autonomy in the conduction of the tasks in order to obtain a service output, it has been observed that customers can show a bias in attributing the responsibilities to the company and the employees (Yen et al. 2004). In service settings with intense customer participation (e.g. retail, education, etc.), the service system evolves towards a production system where employees and customer tasks and instructions are linked and visible for these two actors. Customers will therefore also assess how well the service processes is design to accommodate their participation. As such, in such settings, service quality measure should reflect these aspects, and customer perceptions regarding their capabilities to perform as well as elements related to the sevrcie process operations (e.g. layout, information, etc.)

\subsection{Customer-to-customer interaction}

CCI is a broad concept used to refer to an ample range of interactions that take place between customers during service delivery. In retail settings, for example, customers often engage in conversations with each other to exchange information which facilitates the service process - e.g. asking for help in locating an item in the store, asking for advice or opinions about the suitability of an item for a specific purpose or occasion, etc. - (Harris et. al, 1997). Although CCI is present in a wide variety of service industries, it has been mostly addressed in settings such as retail (see for example Parker and Ward, 2000; Baron et. al, 1996) and travel and leisure services (von Lehn, 2006; Harris and Baron, 2004; Martin, 1997).

The literature documents well the diversity of forms that CCI can assume. McGrath and Otnes (1995) proposed a classification to capture the diverse social and informational exchanges that take place between unacquainted retail customers. Their work distinguished situations in which customers engage in explicit interactions - labeled as overt customer influences - from other instances in which, although customers exert influence over each other's behavior, some of them can be oblivious or even unaware of such interactions - labeled as covert customer influences. Their work documented situations in which customers respond to others facing a problem or a service difficulty (overt influences when customers act as proactive help-seekers, as well as covert influences observed in behaviors of followers and observers); it described also instances when customers presume to have a value or experience to contribute to another 
(overt influences: reactive helpers; as well as covert: judges, accused, spoilers), and also cases where customers provoke some sensory stimulation that has the effect of catching others' attention (covert influences: admirers, complainers) and finally settings in which customers compete for limited resources (overt influences: competitors). Several other authors also contributed to the characterization of the differentiated possible customer roles in CCI, for example by: highlighting the need to distinguish proactive from reactive interaction (e.g. proactive vs. reactive helpers in Parker and Ward (2000)); identifying situations in which CCI results from customer incidents (e.g. Grove and Fisk (1997) distinguished protocol incidents, such as physical and verbal incidents in line, from sociability incidents such as ambiance incidents ) and addressing also dysfunctional customer behavior (e.g. Harris and Reynolds (2004) proposed eight categories of misbehavior - property abusers, oral abusers, vindictive customers, etc.).

Customers' collaboration and socialization is very common in service encounters which take place in the presence of other customers (e.g. public transport, retail, etc.), and can be particularly stimulated when customers have to share time (e.g. wait for the service) or any service resources or utensils (e.g. using self-service technologies). Moreover, CCI is neither restricted to on-site customer interactions, or to the service encounter. Customers often seek for other customers inputs before, or after, a service encounter using a technology interface such as the internet (e.g. a priori searching for customers' opinions' and ratings about a service, or any other word-of-mouth behavior), (Georgi and Mink, 2013; Nicholls, 2005; Harris et. al, 2000).

In some services CCI is not restricted to short interactions between strangers such as the ones described above, but rather, it is one of the main sources of value creation. Examples include tourism and leisure services, such as adventure holidays, for which CCI is an integral element of the intended service experience, and is often planned in advance. The importance and the slightly distinct role of CCI in such services have been acknowledged by being specifically labeled as "CCI-driven services" (Nichols, 2007). The need for further investigation of CCI-driven services has been acknowledged by seminal authors in the field (e.g. Nicholls, 2010), and is further justified by the widespread presence, and importance, of CCI-driven services in our economies - CCI-driven services can be found in a wide variety of industries, such as tourism, education or leisure. Education services, like the ones addressed in this study, have characteristics of "CCI-driven services", as they are designed be provided to groups of customers and often require their participation and collaboration in the process. As such, the measurement of quality in such settings should contemplate items related to the perceived quality of attributes related to the specification and the management of customer groups and their interactions. In this study we will look specifically into these aspects, in order to understand if customers are aware of it being part of service design and specification decisions, for which the service provider is responsible and accountable.

\section{Methodology}

\subsection{Data collection}

The study builds on a preliminary review of the literature about service quality, customer participation and CCI to learn about the extant service quality models, as well as to identify attributes related to customer participation and interaction which could affect service outputs. The purpose was to specify a set of priory categories of service quality attributes to guide the conduction of focus groups interviews, and the subsequent data analysis, following Miiles and Huberman (1994).

Building on the literature review we distinguished three broad dimensions of service delivery performance which can have a determinant impact for service process and service outcomes. A first dimension was related to the direct performance of the service provider, i.e. the resources directly managed and controlled by the company (e.g. service facilities, personnel, etc.). A second dimension was linked to the performance of the customer in his actions and participation in service activities. A third dimension was

Table 1: Service process dimensions influencing service quality

\begin{tabular}{llll}
\hline & Service Process Characteristics & & \\
& Provider & Public & Personal \\
\cline { 2 - 4 } & Tangibility & Time & Arrivals \\
& Responsiveness & Space & Requests \\
Service Quality Dimensions & Assurance & Behaviour & Capabilities \\
& Reliability & Assistance & Motivation \\
& Empathy & & Preferences \\
Key References & Parasuraman et al., 1988, 1991 & Nicholls, 2005 & Frei, F., 2006 \\
\hline
\end{tabular}


considered to contemplate the performance of other customers, and their action an interaction during service delivery (See Table 1).

The proposed three levels of service process dimensions were adopted to analyze the portfolio of educational services offered by the organization addressed in the study - provider of educational, and science, events - in order to characterize service portfolio according to two criteria: the intensity of customer participation required; the number of customers involved in a service event. This classification led to the four process archetypes illustrated in Figure I.

Most of the services offered required substantial customer participation because the education and science labs involved a great deal of experimentation and interaction with the provider employees to analyze and comment the observed experiences or exhibition of scientific aspects (e.g. learning the chemistry involved in producing butter or bread, etc.). The provider offered diverse group activities, for example for school audiences which were monitored by professors and employees of the provider who were responsible for conducting the activities, and assuring the involvement and the engagement of all participants in the experiments. Individual experiences were also provided, where the customers interacted autonomously with the materials and technologies exhibited in the service space. A few services, requiring more modes customers' participation were also offered, such as small exhibitions, and movies and talks with invited guests from the partner university. The provider has a close collaboration with a partner university, located in the same town. Most of the staff involved in the design and conduction of the services (e.g. laboratories for kids, experiment with food and nature, etc,) were current or former researchers from the university.
The next step in the study involved the conduction of 7 focus groups, involving about 12 participants each, including users of the services (i.e. mostly groups of visiting students and professors) and employee, i.e. the monitors involved in the provision of services, for the service categories of Active/Groups and Passive/Groups. The group interviews follow a semi-structured protocol, including a set of guiding questions regarding the service experience, and the preparation undergone by customers and employees before a service experience. The purpose was to explore service delivery aspects found by each of these actors as relevant for the successful service experience. The interviews are recorded and subsequently transcribed for data analysis and coding.

\subsection{Data analysis}

Data analysis involved the identification of relevant quality attributes related to the three service dimensions specified ex-ante, from the exploration of the transcribed interviews. Relevant aspects were summarized into in an adequate display, an analysis strategy recommended by Miles and Huberman (1994). We built separate matrices for summarizing the service quality aspects mentioned by employees, and by professors and student customers, in an effort to categorize then under one of the three dimensions: provider's direct performance, customer performance, and CCI performance. We began by building a comprehensive list of quality attributes that were classified into those broader conceptual categories. This resulted in a comprehensive list of aspects supported by the literature and a few new aspects which were not found in the literature review

Intensity of customer participation

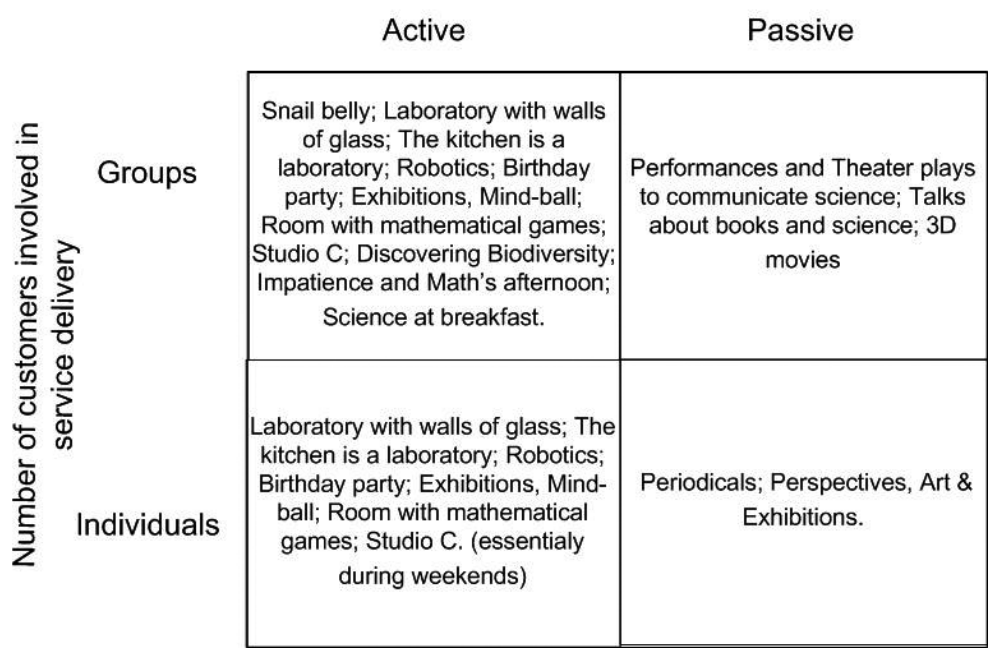

Figure 1: Service process archetypes 
(mostly linked with the customer participation and interaction issues, as expected). Staff members involved the focus groups involved the front-office people responsible for the reservation and hosting of visiting groups, as well as the monitors who were involved in the direct conduction of the service experiences. Most of these were young researchers that came from the partner university which collaborated with the service provider. It also included back-office staff involved in the management of the facilities and equipment and on the preparation of materials for service activities (e.g. chemicals or ingredients for the experiments).

\section{Study results}

In the interviews, the different groups expressed several aspects that were regarded with particular importance in order to assure the quality of the service that matched the proposed three levels of service dimensions. In Figure II we illustrate some of such aspects derived from the focus groups involving elements of the museum staff.

Some of them were linked to dimensions addressed in service literature, such as tangible elements or reliability

\begin{tabular}{|c|c|c|c|}
\hline \multicolumn{2}{|c|}{ Service Quality Dimensions } & Quotes & \multirow[t]{2}{*}{$\begin{array}{l}\text { Relative } \\
\text { Importance }\end{array}$} \\
\hline \multirow[t]{5}{*}{ Provider } & $\begin{array}{l}\text { Quality of the } \\
\text { Scientific Content of } \\
\text { the Service }\end{array}$ & $\begin{array}{l}\text { "...often we prepare a general content } f[\text { for a service or activity] and then we } \\
\text { adopt it to the level of the audience we receive. }\end{array}$ & \\
\hline & Tangible Aspects & $\begin{array}{l}\text { "It's an old building which was recovered from other use and it's not very } \\
\text { ready to be accessible. However it ends up to be warm and welcoming." } \\
\text { "Lacks accessibility for people with reduced mobility and for some } \\
\text { children." }\end{array}$ & + \\
\hline & Promotion and Access & $\begin{array}{l}\text { "People complain a lot about the difficulties they have in understanding the } \\
\text { schedule for the various services provided. Usually there are doubts about } \\
\text { what exactly is available in a given day." }\end{array}$ & + \\
\hline & Reliability & $\begin{array}{l}\text { "We make sure that the colleagues leave everything in place whenever a } \\
\text { session ends, in order for everything to be ready for the next session or } \\
\text { activity. We also check the type o audience that we are receiving before each } \\
\text { activity starts in order to make any adaptations to peoples' age, for example." }\end{array}$ & + \\
\hline & Responsiveness & $\begin{array}{l}\text { "Each session is available at several different schedules throughout the day. } \\
\text { This is a good solution for receiving people who arrive without prior } \\
\text { reservation....we can find always activities for them." }\end{array}$ & + \\
\hline \multirow[t]{7}{*}{ Customer } & Arrivals & $\begin{array}{l}\text { "Sometimes some people arrive late and they miss the first activities } \\
\text { scheduled for the group." }\end{array}$ & - \\
\hline & Prenaration & $\begin{array}{l}\text { "Some students have come to experiment the same activity with } \\
\text { accompanied by different professors, whereas there are many different } \\
\text { activities that they could try of they could organize for it..." }\end{array}$ & +4 \\
\hline & Fеран airoil & $\begin{array}{l}\text { "Often, the person from the school who calls to make the reservation doesn't' } \\
\text { have a clear idea of the service they're booking. Then when students come } \\
\text { they just find out." }\end{array}$ & \\
\hline & & $\begin{array}{l}\text { "The staff ness feedback from students during the activity in order to } \\
\text { understand if its going as predicted." }\end{array}$ & 1 \\
\hline & Feedback & $\begin{array}{l}\text { "If the students don't answer the staff, or are rude or just playful, it can } \\
\text { become very hard to manage a session or an activity and keep it on track." }\end{array}$ & \# \\
\hline & Motivation & $\begin{array}{l}\text { "In some ages students are very irreverent, by nature, so they're not always } \\
\text { cooperative, and we need to handle this the best way in order to perform the } \\
\text { sessions or activities." }\end{array}$ & - \\
\hline & Effort & $\begin{array}{l}\text { "The activities proposed are not difficult, but some might require some } \\
\text { reading or other preparation effort before they can put hands on." }\end{array}$ & + \\
\hline \multirow{3}{*}{ CCI } & Assistance & $\begin{array}{l}\text { "When students come in groups, they already know each other and this is } \\
\text { good because they debate the issues being experienced between them." }\end{array}$ & + \\
\hline & & "The activities work better with groups of $15-20$ students." & \\
\hline & Number of Participants & $\begin{array}{l}\text { "...the number of participants should be reduced...to handle } 25 \text { people in a } \\
\text { session is not easy." }\end{array}$ & + \\
\hline
\end{tabular}

Figure 2: Service quality aspects mentioned by staff in focus-group interviews 
issues. However, the conversations also provided evidence that aspects related to the performance of the customers (e.g. their preparation for the visit, or their motivation to collaborate in the activities proposed by the provider) were key for the service experience. Likewise, aspects related to the dimension of visiting groups, and to the way they interacted during the service (e.g. mutually motivating by competing to the completion of activities) were also found to be critical to affect the quality of the experiences.

The groups of students and customers interviews revealed similar results, i.e. mentioning aspects related to the provider and to the customer performance as determinant for overall service outcomes and quality. Nevertheless, the distinct groups would place more emphasis in distinct dimension or items, depending on their profiles and previous experiences they had with the service. In Figures 3 and 4 we list the dimensions that emerged from the interviews with these groups, and provide some illustrative quotes from the conversations.

The professors expressed a great concern with the scientific content of the service experience, and the need to align it with the contents addressed in the school with the students. They understood the educational services of the provider as a potential important complement to the work done in school, but highlighted that in order for this to be effective the alignment and the preparation of the visit were essential.

In the student interviews, the aspects related to the individual performance and the quality of the participation of them became much more salient in the conversations.
Students recognized the importance of having activities suited to their capabilities and, like professors and staff did, they highlighted the determinant role that some beforehand preparation for the activity could have for its outcome. They were particularly expressive when commenting about aspects related to the interaction with other customers. They referred to the impact that lack of control on the behavior of other groups could have for the experience (e.g. noise). Moreover, they brought to the discussion a whole set of new aspects, for example, issues related to the competition between groups and how it could impact the engagement in the conduction of the activities proposed by the provider. At the time of the study, the provider was not explicitly specifying competition or collaboration among groups in the design of the proposed activities. However, the results suggest that aspects like these can be key service process design issues, which have a determinant role for service outcomes.

\section{Conclusion}

In this study we proposed to explore aspects related to the design of service delivery processes involving customer participation, which are determinant for service outcomes and customer quality perceptions. Our research was driven by the observation that whereas there is some generalization of services involving customer participation and CCI, extant service quality models predominately address aspects related to customer-provider interactions, and the quality of service providers' resources (e.g. employees, tangibles,

\begin{tabular}{|c|c|c|c|}
\hline \multicolumn{2}{|c|}{ Service Quality Dimensions } & & $\begin{array}{l}\text { Relative } \\
\text { Importance }\end{array}$ \\
\hline Provider & $\begin{array}{l}\text { Quality of the } \\
\text { Scientific Content of } \\
\text { the Service }\end{array}$ & $\begin{array}{l}\text { "The scientific content of the activities proposed must be aligned with the } \\
\text { participants school year." }\end{array}$ & + \\
\hline \multirow[t]{4}{*}{ Customer } & Tangible Aspects & "The facilities are well organized and equipped." & + \\
\hline & Promotion and Access & $\begin{array}{l}\text { "It would be important to provide more information beforehand and } \\
\text { documentation about the scientific content in order to better prepare the } \\
\text { groups for the activities that they will engage during the visit." }\end{array}$ & - \\
\hline & Capability & "Students have the capabilities to engage in the activities proposed." & $+H$ \\
\hline & Motivation & $\begin{array}{l}\text { "It is harder to motivate older students to be engaged and to participate } \\
\text { actively in the activities." }\end{array}$ & + \\
\hline \multirow[t]{3}{*}{ CCI } & & $\begin{array}{l}\text { "Usually students organize themselves into groups to participate in the } \\
\text { proposed activities." }\end{array}$ & \\
\hline & Assistance & $\begin{array}{l}\text { "Student groups engage into competition with each other in order to see who } \\
\text { complete the proposed activities first." }\end{array}$ & + \\
\hline & Number of Participants & $\begin{array}{l}\text { "When the number of people in a group is very numerous it can become very } \\
\text { difficult for them [staff] to help all student finish the proposed activities." }\end{array}$ & + \\
\hline
\end{tabular}

Figure 3: Service quality aspects mentioned by customers (professors) in focus-group interviews 


\begin{tabular}{|c|c|c|c|}
\hline \multicolumn{2}{|c|}{ Service Quality Dimensions } & Quotes & $\begin{array}{l}\text { Relative } \\
\text { Importance }\end{array}$ \\
\hline Provider & Reliability & $\begin{array}{l}\text { "The activities give the opportunity to deepen the knowledge." } \\
\text { "They [staff] explain things in a way which is easy to understand." } \\
\text { "They [staff] are very patient." }\end{array}$ & + \\
\hline & Tangible Aspects & $\begin{array}{l}\text { "The facilities are well decorated." } \\
\text { "...The learning spaces are well equipped and facilitate the communication } \\
\text { of the scientific contents." }\end{array}$ & + \\
\hline & Promotion and Access & $\begin{array}{l}\text { "Honestly I was not aware of what this [service facilities] was. I didn't even } \\
\text { know it existed. I believe that the promotion of the service should be better." } \\
\text { "In my opinion it is not well signalled [service facilities]. One doesn't even } \\
\text { see a sign saying [name of the provider] when we are approaching." }\end{array}$ & + \\
\hline & $\begin{array}{l}\text { Quality of the } \\
\text { Scientific Content of } \\
\text { the Service }\end{array}$ & $\begin{array}{l}\text { "The contents are relevant." } \\
\text { "We deepen the knowledge about scientific contents but also about our } \\
\text { region and resources." } \\
\text { "The contents and knowledge transmitted in the activities are aligned with } \\
\text { the school programs and are useful to complement our work." }\end{array}$ & + \\
\hline \multirow[t]{3}{*}{ Customer } & Capability & $\begin{array}{l}\text { "The activities are simple and easy to understand." } \\
\text { "...the learning experience provided is different from school because }(\ldots) \text { is } \\
\text { very practical." }\end{array}$ & + \\
\hline & Motivation & $\begin{array}{l}\text { "They [service staff] make us want to listen to them." } \\
\text { "We feel at ease to participate and try the activities." }\end{array}$ & + \\
\hline & Preparation & $\begin{array}{l}\text { "...often the professors talk about the [name of the company] beforehand but } \\
\text { we don't understand very clearly what it is." }\end{array}$ & - \\
\hline \multirow[t]{4}{*}{ CCI } & & "When opinions differ they try to struggle to see who's right." & \\
\hline & Assistance & $\begin{array}{l}\text { "When there are other schools present we try to give our best to be better in } \\
\text { the activities and experiences." }\end{array}$ & + \\
\hline & Verbal Behaviour & $\begin{array}{l}\text { "Usually there are comments when different schools are present in the same } \\
\text { activity and are trying to compete with each other." }\end{array}$ & - \\
\hline & Number of Participants & $\begin{array}{l}\text { "For some activities it would be better to split the group in half." } \\
\text { "Its easier when there are fewer people...we can do more activities and we } \\
\text { can pay more attention to the monitors [staff employees) and to the } \\
\text { details..." } \\
\text { "If the group is smaller there's more interaction. If the group is bigger it is } \\
\text { more organized as nobody wants to talk..." }\end{array}$ & + \\
\hline
\end{tabular}

Figure 4: Service quality aspects mentioned by customers (students) in focus-group interviews

etc.). We conducted focus groups with customers and staff of a leading education services provider, which offered a portfolio of scientific educational activities, a rich context of customer participation and CCI. Data analysis supported that both customers and staff are aware of the importance of issues related to the customer participation (e.g. motivation, capabilities, etc.), as well as of aspects related to the dynamics created by groups of customers sharing the same service facilities. The results support that customers are aware of the importance of such aspects for the quality of the service outcome, and that, to some extent they attribute its specification to the responsibility of the service provider. Service processes involve successive operations, during which the service setting and the providers' decisions (e.g. staff choices, target customers, customer group dimensions, etc.) are highly visible for customers, and therefore subject to their assessment. As such, the results support our research intuition that service quality approaches need to be extended to encompass aspects related to customer participation and interaction. This study therefore contribute to expand service quality frameworks and to inform the design and the management of services where customer participation and 
CCI have a key role. The conduction of further exploratory analysis in other service settings would be useful to further develop this line of work, and to prepare adequate measurement tools to address service quality in such settings.

\section{References}

Baker, J. \& Lamb, \& C. W. (1994). Measuring architectural design service quality. Journal of Professional Services Marketing, 10(1), 89-106, http://dx.doi.org/10.1300/J090v10n01_10

Baron, S., Harris, K., \& Davies, B.J. (1996). Oral participation in retail service delivery: a comparison of the roles of contact personnel and customers. European Journal of Marketing, 30(9), 75-90, http://dx.doi.org/10.1108/03090569610130052

Bendapudi, N., \& Leone, R. P. (2003). Psychological implications of customer participation in co-production. Journal of Marketing, 67(1), 14-28, http://dx.doi.org/10.1509/ jmkg.67.1.14.18592

Burke, R. R. (2002). Technology and the customer interface: what consumers want in the physical and virtual store. Journal of the Academy of Marketing Science, 30(4), 411-432, http:// dx.doi.org/10.1177/009207002236914

Chase, R. B. (1981), Customer contact approach to services: theoretical bases and practical extensions. Operations Research, 29(4), 698-706, http://dx.doi.org/10.1287/opre.29.4.698

Cheung, M. F., \& To, W. M. (2011). Customer involvement and perceptions: The moderating role of customer co-production. Journal of Retailing and Consumer Services, 18(4), 271-277, http://dx.doi.org/10.1016/j.jretconser.2010.12.011

Dabholkar, P.A., Thorpe, D.I., \& Rentz, J.O. (1996). A measure of service quality for retail stores: scale development and validation. Journal of the Academy of Marketing Science, 24 (1), 3-16, http://dx.doi.org/10.1177/009207039602400101

Ford, R. C., \& Dickson, D. R. (2012). Enhancing customer self-efficacy in co-producing service experiences. Business Horizons, 55(2), 179-188, http://dx.doi.org/10.1016/j.bushor.2011.11.005

Frei, F. (2006). Breaking the trade-off between efficiency and service. Harvard Business Review, 84 (11), 92-101.

Georgi, D., \& Mink, M. (2013). eCCIq: The quality of electronic customer-to-customer interaction. Journal of Retailing and Consumer Services, 20(1), 11-19, http://dx.doi.org/10.1016/j. jretconser.2012.08.002

Goldstein, S. M., Johnston, R., Duffy, J. A., \& Rao, J. (2002). The service concept: the missing link in service design research? Journal of Operations Management, 20(2), 121-134, http:// dx.doi.org/10.1016/S0272-6963(01)00090-0

Grönroos, C., \& Ojasalo, K. (2004). Service productivity: towards a conceptualization of the transformation of inputs into economic results in services. Journal of Business Research, 57(4), 414-423, http://dx.doi.org/10.1016/S0148-2963(02)00275-8

Grönroos, C. (1998). Marketing services: the case of a missing product. Journal of Business and Industrial Marketing, 13(4/5), 322-338, http://dx.doi.org/10.1108/08858629810226645

Grönroos, C. (1993). A Service Quality Model and its Marketing Implications. European Journal of Marketing, 18 (4), 36 - 44, http://dx.doi.org/10.1108/EUM0000000004784
Grove, S.J., \& Fisk, R.P. (1997). The impact of other customers on service experiences: a critical incident examination of 'getting along'. Journal of Retailing, 73(1), 63-85.

Harris, K., Baron, S., \& Parker, D. (2000). Understanding the consumer experience: it's 'good to talk'. Journal of Marketing Management, 16, 111-27, http://dx.doi. org/10.1362/026725700785100505

Harris, K., Davies, B. \& Baron, S. (1997). Conversations during purchase consideration: sales assistants and customers. International Review of Retail Distribution and Consumer Research, 7(3), 173-90, http://dx.doi. org/10.1080/095939697342987

Heinonen, K., Strandvik, T., \& Voima, P. (2013). Customer dominant value formation in service. European Business Review, 25(2), 104-123, http://dx.doi.org/10.1108/09555341311302639

Huang, W. H., Lin, Y. C., \& Wen, Y. C. (2010). Attributions and outcomes of customer misbehavior. Journal of Business and Psychology, 25(1), 151-161, http://dx.doi.org/10.1007/ s10869-009-9137-x

Johnston, R., \& Clark, G. (2008), Service Operations Management, 3nd ed., Harlow, England: FT Prentice Hall,

Johnston, R., \& Clark, G. (2005). Service operations management: improving service delivery. Harlow, England: Prentice Hall.

Kelley, S. W., Skinner, S. J., \& Donnelly, J. H. (1992). Organizational socialization of service customers. Journal of Business Research, 25(3), 197-214, http://dx.doi.org/10.1016/01482963(92)90029-B

Ladhari, R. (2009). A review of twenty years of SERVQUAL research. International Journal of Quality and Service Sciences, 1(2), 172-198, http://dx.doi.org/10.1108/17566690910971445

Lovelock, C. H., \& Wirtz, J. (2001), Services marketing: people, technology, strategy, Prentice Hall.

Lovelock, C. H., \& Gummesson, E. (2004). Whither services marketing? In search of a new paradigm and fresh perspectives. Journal of Service Research, 7(1), 20, http://dx.doi. org/10.1177/1094670504266131

Martin, C. L., \& Pranter, C. A. (1989). Compatibility management: customer-to-customer relationships in service environments. Journal of Services Marketing, 3(3), 5-15, http://dx.doi. org/10.1108/EUM0000000002488

Martínez, J. A., \& Martínez, L. (2010). Some insights on conceptualizing and measuring service quality. Journal of Retailing and Consumer Services, 17(1), 29-42, http://dx.doi.org/10.1016/j. jretconser.2009.09.002

McGrath, M. A., \& Otnes, C. (1995). Unacquainted influencers: when strangers interact in the retail setting. Journal of Business Research, 32(3), 261-272, http://dx.doi.org/10.1016/01482963(94)00051-F

Miles, M.B., \& Huberman, A.M. (1994). Qualitative Data Analysis: An Expanded Source Book. Thousand Oaks, CA: Sage

Mills, P. K., Chase, R. B. \& Margulies, N. (1983). Motivating the client/employee system as a service production strategy. Academy of Management Review, 8(2), 301-310, http:// dx.doi.org/10.5465/AMR.1983.4284740

Mills, P. K., \& Margulies, N. (1980). Toward a core typology of service organizations. Academy of Management Review, 5(2), 255-265, http://dx.doi.org/10.2307/257435

Mills, P. K., \& Morris, J. H. (1986). Clients as 'partial'employees of service organizations: role development in client participation. Academy of Management Review, 11(4), 726-35, http:// dx.doi.org/10.5465/AMR.1986.4283916 
Mohr, L. A., \& Bitner, M. J. (1995). The role of employee effort in satisfaction with service transactions. Journal of Business Research, 32(3), 239-252, http://dx.doi.org/10.1016/01482963(94)00049-K

Nicholls, R. (2010). New directions for customer-to-customer interaction research. Journal of Services Marketing, 24(1), 87-97, http://dx.doi.org/10.1108/08876041011017916

Nicholls, R. (2007). Value creation in services: a customer-to-customer (C2C) approach. In: Starnawska, S. \& Werda, W. (Eds). In: Search for Value: Selected Aspects, Siedlce: University of Podlasie, pp. 79-84.

Nicholls, R. (2005). Interactions between Service Customers: Managing On-site Customer-to-customer Interactions for Service Advantage. Poznan: The Poznan University of Economics Publishing House.

Parasuraman, A., Zeithaml, V. A., \& Malhotra, A. (2005). Value creation in services: a customer-to-customer (C2C) approach. Journal of service Research, 7(3), 213-234, http://dx.doi. org/10.1177/1094670504271156

Parasuraman. A., Berry L. L., \& Zelthaml V. A. (1991). Refinement and Reassessment of the SERVQUAL Scale. Journal of Retailing, 67 (Winter), 420-450.

Parasuraman, A., Zeithaml, V. A., \& Berry, L. L. (1988). SERVQUAL: A Multiple-Item Scale for Measuring Consumer Perceptions of Service Quality. Journal of Retailing, 64 (Spring), 12-40.

Parker, C., \& Ward, P. (2000). An analysis of role adoptions and scripts during customer-to-customer encounters. European Journal of Marketing, 34(3/4), 341-359, http://dx.doi. org/10.1108/03090560010311894

Payne, A. F., Storbacka, K., \& Frow, P. (2008). Managing the co-creation of value. Journal of the Academy of Marketing Science, 36(1), 83-96, http://dx.doi.org/10.1007/s11747-0070070-0

Prahalad, C. K., \& Ramaswamy, V. (2004). Co-creation experiences: the next practice in value creation. Journal of Interactive Marketing, 18(3), 5-14, http://dx.doi.org/10.1002/dir.20015

Rosenbaum, M. S., \& Massiah, C. (2011), An expanded servicescape perspective. Journal of Service Management, 22(4), 471490, http://dx.doi.org/10.1108/09564231111155088

Roth, A. V., \& Menor, L. J. (2003). Insights into service operations management: A research agenda. Production and Operations Management, 12(2), 145-164, http://dx.doi. org/10.1111/j.1937-5956.2003.tb00498.x

Sampson, S. E. (2007), Customer Roles in Service Supply Chains, Proceedings of the Decision Sciences Institute Annual Meeting DSI, Atlanta, November, 2007.
Sampson, S. E. \& Froehle, C. M. (2006). Foundations and implications of a proposed unified services theory. Production and Operations Management, 15(2), 329-343, http://dx.doi. org/10.1111/j.1937-5956.2006.tb00248.x

Sampson, S. E. (2000). Customer-supplier duality and bidirectional supply chains in service organizations. International Journal of Service Industry Management, 11(4), 348-364, http:// dx.doi.org/10.1108/09564230010355377

Tax, S. S., Colgate, M., \& Bowen, D. E. (2006). How to prevent your customers from failing. MIT Sloan Management Review, 47(3), 30-38.

Vom Lehn, D. (2006). Embodying experience: a video-based examination of visitors' conduct and interaction in museums. European Journal of Marketing, 40(11/12), 1340-1359, http:// dx.doi.org/10.1108/03090560610702849

Yen, H. R., Gwinner, K. P., \& Su, W. (2004). The impact of customer participation and service expectation on locus attributions following service failure. International Journal of Service Industry Management, 15(1), 7-26, http://dx.doi. org/10.1108/09564230410523312

Marlene Amorim is an Assistant Professor at the Department of Economics Management and Industrial Engineering and Invited Assistant Professor at the Catholic University in Porto for field Service quality and Innovation. Marlene is a researcher at GOVCPP (Research Unit on Governance Competitiveness and Public Policies) and conducts research in the area of service operations and service quality, notably in topics related to service process design and customer participation in service delivery.

Maria João Rosa is an Assistant Professor at the Department of Economics Management and Industrial Engineering and a researcher at CIPES (Centre for Research in Higher Education Services). She conducts research in the field of quality management, notably addressing the quality of education services.

Sandra Santos is a researcher in the field of service quality and customer participation. She completed a Master degree in Industrial Engineering and Management at the University of Aveiro, and her research focuses on the application of operations management principles to service delivery processes. 